\title{
NOG IETS OVER EEN BALINEESCHEN KALENDER
}

\author{
Door W. O. J. NIEUWENKAMP.
}

(Met 5 tekst-afbeeldingen).

In mijn beschrijving van een Balineeschen kalender in dit zelfde tijdschrift ${ }^{1}$ heb $\mathrm{ik}$ de verschillende ingesneden merken en ingestoken stiften besproken, en aangegeven wat deze te beduiden hebben. Door den Sumatra-reiziger ALFRED MAASS te Berlijn, die mij over dit onderwerp inlichtingen vroeg, werd ik opmerkzaam gemaakt dat door mij in bovengenoemd artikel wel de verklaring van de 11 verschillende teekens was opgegeven, maar niet de juiste plaatsing daarvan, dus niet de vakjes waarin ze voorkomen.

$\mathrm{Nu}$ is de plaatsing van de vijf weekdag-teekens, $\mathrm{N}^{\text {os }} .1,2$, 3,4 en $5^{2}$ gemakkelijk na te gaan, door eenvoudige aftelling van de vakjes, daar zij bepaalde dagen aanduiden, te weten: $\mathrm{N}^{\circ}$. 1 is de eerste dag van de 9-daagsche week, $\mathrm{N}^{\circ} .2$, de eerste dag van de 8-daagsche week, $\mathrm{N}^{\circ} .3$, de derde dag van de 6-daagsche week, $\mathrm{N}^{\circ} .4$, de derde dag van de 8-daagsche week en $\mathrm{N}^{\circ} .5$, de zevende dag van de 8-daagsche week.

Van de horoscoopteekens $\left(\mathrm{N}^{\circ} \text {. } 6 \text { tot } 11\right)^{3}$ is de plaatsing echter niet bepaald en, zooals de Heer Maass terecht opmerkt, is die ook niet op plaat I of II in mijn vorig artikel te onderscheiden. Om dit verzuim nu goed te maken bied ik hierbij een 4-tal schema's aan, waarop de juiste plaatsing van deze 6 horoscoopteekens is aangeduid.

Op het eerste schema ziet men het teeken $\mathrm{N}^{\circ}$. 6, Pamatjękan lanang, in $84^{*}$ vakjes. Nu de plaatsing van dit "mannelijk teeken" afzonderlijk is afgebeeld, valt dadelijk op, hetgeen op den kalender zelf, tusschen al die andere teekens

1 Deel 69 , 1914, blz. 112-126.

2 Zie de af beelding daarvan op blz. 120, l.c.

3 Zie de afbeelding als voren.

4 In mijn vorig artikel staat op blz. 120 , laatste regel, abusievelijk 85 . 


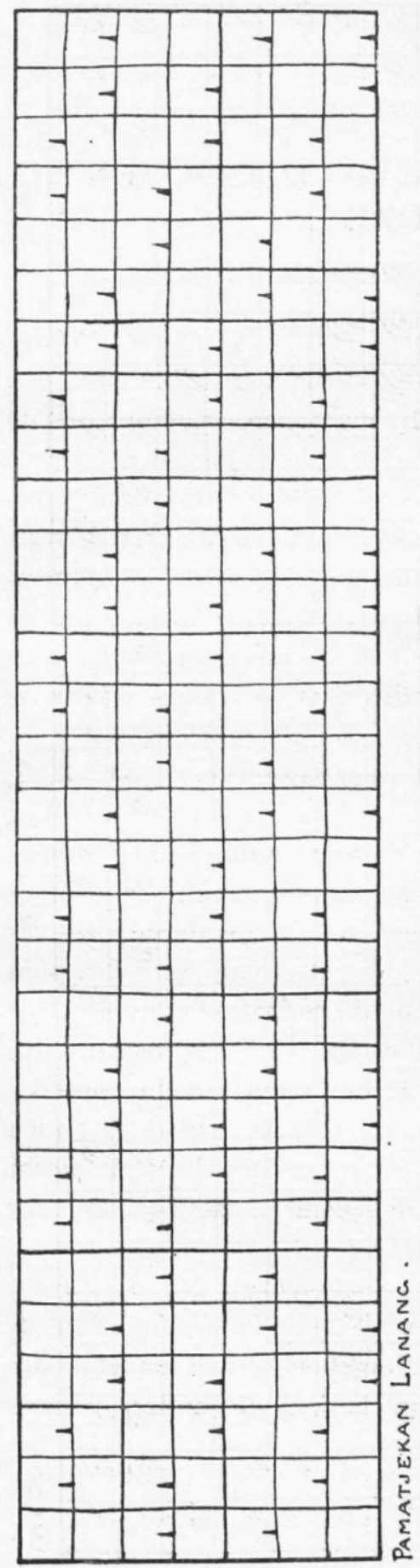

Schema No. 1 .

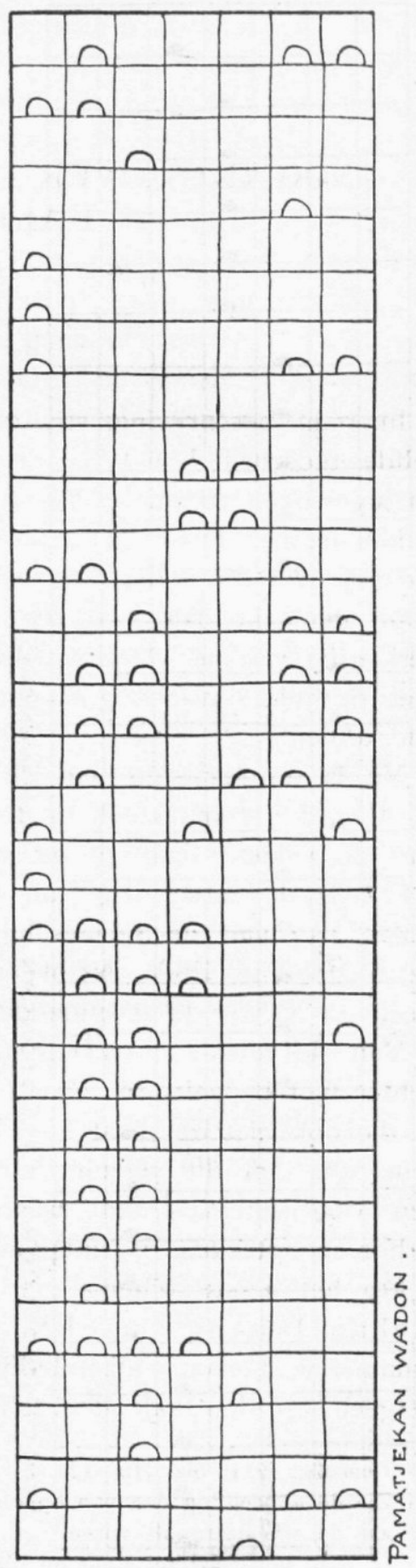

Schema $N^{\circ} .2$. 


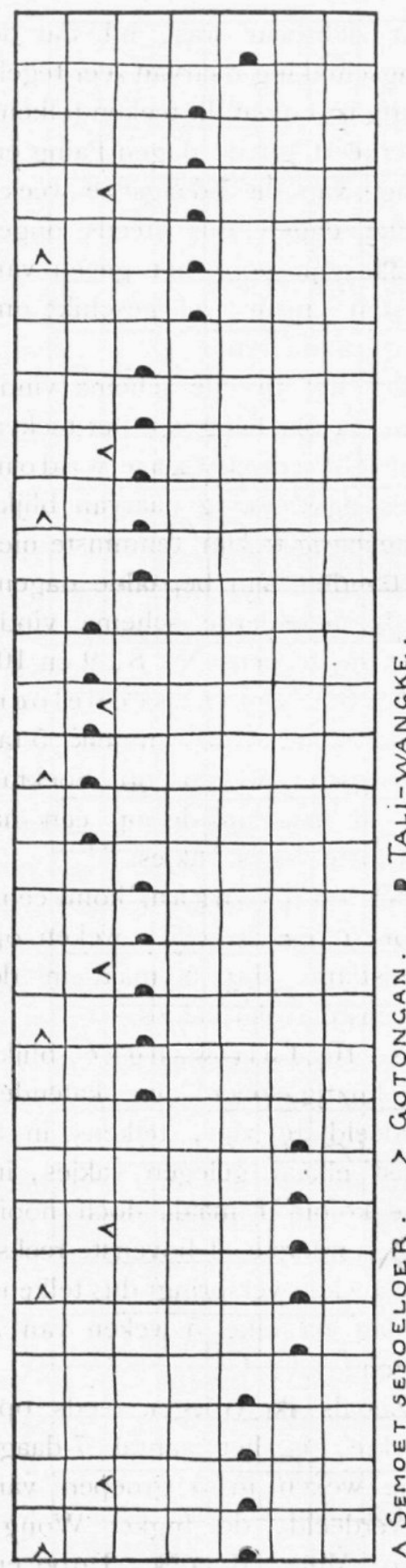

Schema No. 3.

\begin{tabular}{|c|c|c|c|c|c|c|}
\hline I) & एग & P & ए & $\Gamma$ & נעי & ए \\
\hline & עית & IJ & 5 & F & $\sqrt{5}$ & ש \\
\hline & תק & ק & 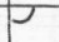 & תש & נעי & 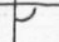 \\
\hline עy & (I) & נש & ग & F & נעש & $\approx$ \\
\hline עय & $P$ & J & प्र & F & F & 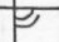 \\
\hline एग & गु & J & & עת & श्צ & $P$ \\
\hline תע & עצ" & עy & 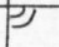 & & עעי & ק \\
\hline עצע & ע & ק & עש & (1) & י & T \\
\hline , & עy & T & P & Tr & עy & ק \\
\hline שת & & קעיש & P & $p$ & קעל & $p$ \\
\hline प्र & שת & $P$ & ק & एग & עיש & עש \\
\hline E & ש & קע & $F$ &  & עש & עי \\
\hline 匈 & 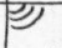 & ए & $p$ & $p$ & נציש & j \\
\hline נر & एण & 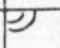 & ק & ק & p & נעש \\
\hline 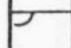 & एग & ע & עy & ए & ए & J \\
\hline תע & תק & עי & J & ק & ק्य & תוש \\
\hline 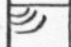 & קر & $\pi$ & תע & ק & עי & DI \\
\hline עय & एע & 5 & У & رעי & एग & 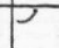 \\
\hline עי & श्र & श्र & P & & קיע & ק \\
\hline ए & |गु & עy & נעי & 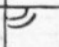 & $T$ & ர्্ \\
\hline עית & עय & $P$ & F & ர्र & קעy & $P$ \\
\hline ग & ए & एע & "I & P & ए & נינ \\
\hline שֶ, & עy & & हु & ת & ע. & ர्্ \\
\hline " & رע & ர्र & . & ע & ர্ত্ & (ע) \\
\hline ע & תעש & J & עו & ע & (ע) & ק \\
\hline 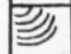 & ע & F & एग & ש & ק & ק \\
\hline J & (ע) & עת & עy & J & J & P \\
\hline (Y) & श) & ए & I & ק & נעש & ग \\
\hline ת) & נ) & ק & J & P & עת & עת \\
\hline ए & (עת) & ע & ת & (ग) & ए & \\
\hline
\end{tabular}

Schema No. 4. 


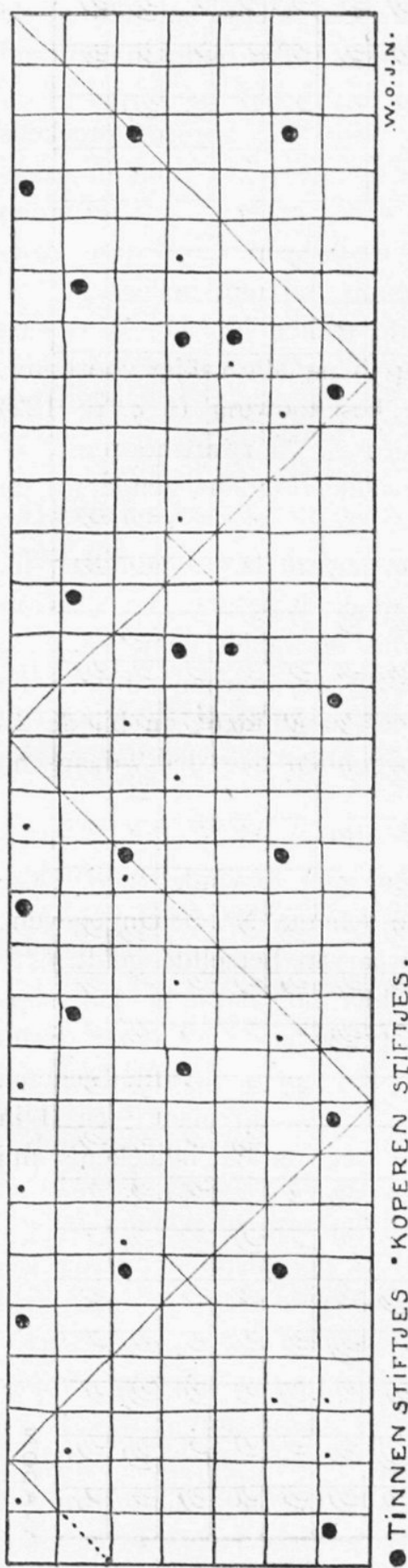

Schema No. 5 .

niet zichtbaar was, n.l. dat de rangschikking daarvan zeer regelmatig is; en dat dit teeken telkens weerkeert op de dagen Paing en Wage van de 5-daagsche week, welke dagen dus steeds ongeschikt zijn voor het geven van feesten, maar wel geschikt om te gaan offeren.

Op het tweede schema vindt men de plaatsing van het teeken $N^{\circ} .7$, Pamatjěkan wadon. De rangschikking daarvan blijkt willekeurig te zijn, tenminste niet verbonden aan bepaalde dagen.

Op het derde schema vindt men de teekens $\mathrm{N}^{\circ}$. 8, 9 en 10.

$\mathrm{N}^{\circ} .8$, Sermoet sědoeloer, komt ééns voor in elk 5-tal 7-daagsche weken op Soekra, dus 6 maal in de op één na bovenste reeks vakjes.

No. 9, Gotongan, komt ééns voor in de 5 zelfde weken op Sanistjara, dus 6 maal in de bovenste reeks vakjes.

$\mathrm{N}^{\circ} \cdot 10$, T a li-wangke, blijkt regelmatig over den kalender verdeeld te zijn, telkens in 5 naast elkaar gelegen vakjes, in elke kolom 1 maal, doch nooit in de onderste of bovenste reeks. Het teeken verspringt dus telkens 1 dag na elke 5 weken van 7 dagen.

Zooals ik vroeger reeds opmerkte, is het aantal 7-daagsche weken in 5 groepen van 6 verdeeld, de Ingkěl Wong, Sato, Mină, Manoek, Taroe en 
Boekoe, ${ }^{1}$ waarvan (en dit nog als een kleine aanvulling) de Ingkěl Wong telkens door een hoornen stiftje onder in den rand van den kalender is aangegeven.

Bij het bezien van de verdeeling van de 3 horoscoopteekens 8,9 en 10 blijkt nu dat er nog een andere indeeling in weekgroepen bestaat, n.l. in 6 groepen van 5 weken, in elke groep waarvan deze 3 teekens regelmatig wederkeeren. Of deze groepen ook afzonderlijke nsmen hebben is mij niet bekend.

Op het vierde schema is ingevuld teeken $\mathrm{N}^{\circ}$. $11, \mathrm{~W}$ adon, dat, van 1 tot 5 maal bijeen, in op 5 na alle vakjes voorkomt.

Verder sprak ik in mijn vorige beschouwing (1. c. p. 122) over 42 ivoren stiftjes, 35 wit-hoornen, 23 zwart-hoornen, 21 tinnen (in mijn vorig artikel abusievelijk «looden» genoemd), en 19 koperen pennetjes.

Daar de 42 ivoren stiftjes een bepaalden dag aanduiden, nl. den vierden dag van de 5-daagsche week, is de plaatsing daarvan weder door eenvoudige aftelling van de vakjes gemakkelijk te vinden. Dit is ook het geval bij de 35 wit-hoornen stiftjes, die den zesden dag der 6-daagsche week aanduiden, en bij de 23 zwart-hoornen stiftjes, die elken negenden dag der 9-daagsche weken bepalen.

Anders is het met de 21 tinnen stiftjes, die geen bepaalden dag aanduiden, en dus zonder meer niet te vinden zijn. Deze heb ik daarom in het toegevoegde schema $\mathrm{N}^{\circ}$. 5 aangegeven, evenals de 19 koperen pennetjes, waarvan hetzelfde geldt.

Voor de volledigheid vermeld ik hier nog dat in het kalenderplankje nog een dunne zigzaglijn gesneden is, telkens dwars door 7 banden van 7 vakjes, zooals op dat vijfde schema ook is aangegeven. Van deze lijn, die ook op plaat I en II in mijn vorig artikel te onderkennen valt, is de beteekenis mij echter niet bekend.

1 Zie blz. 123 , 1. c. 